\title{
Status of Farm Mechanization in Durg, Balod District of Chhattisgarh Plains-A Case Study
}

\author{
Dipti Sahu* and Vinod Kumar Sahu
}

${ }^{1}$ Department of Farm Machinery and Power Engineering, Vaugh School of Agricultural

Engineering and Technology, Sam Higginbotton Institute of Agriculture, Technology and science, Allahabad (U.P.), India

${ }^{2}$ (Agricultural Engineering) Chhattisgarh Agriculture Engineering College, Bhilai, Durg

(Chhattisgarh), India

*Corresponding author

\section{Ke y w o r d s \\ Farm mechanization, Durg, Balod, Self propelled equipments}

\section{Article Info}

Accepted:

10 April 2020

Available Online:

10 May 2020

\section{A B S T R A C T}

A study was conducted in Balod District of Chhattisgarh Plains in Chhattisgarh state to assess the level of draft animal power utilization, tractor utilization, power availability and women's power contribution in agricultural and allied activities. By personal interview using a structured questionnaire 30 respondents selected in each of the village. In Gunderdehi Block Arjunda and Lohara village whereas in Gurur Block Latabod and Sikosa village was selected. The level of farm mechanization in the Balod has progressive stage. The draught power utilization was on higher side in the month of May, June, July and August due to time of tillage and intercultural operation for paddy crop. The He-buffaloes power category the highest utilization per pair was recorded $342.5 \mathrm{~h}$ in village Lohara and lowest $211.5 \mathrm{~h}$ in village Sikosa, rest of village Latabod and Arjunda $301.6 \mathrm{~h}$ and $224.6 \mathrm{~h}$ respectively. The highest utilization of He-buffaloes power use/ha was noted in village Lohara and it was $118.55 \mathrm{~h} / \mathrm{ha}$ and lowest was $50.26 \mathrm{~h} / \mathrm{ha}$ in village Sikosa. The average annual use of the tractors was $382 \mathrm{~h}$ only in the district out of which for $59.16 \%$ of the time, the tractors were used for custom work and that of $40.85 \%$ of the time, for own work. Average farm power availability in Balod district and selected villages is 1.093 $\mathrm{kW} / \mathrm{ha}$ and $1.62 \mathrm{~kW} / \mathrm{ha}$ respectively. Mean time spent by the women respondents was 8.63 $\mathrm{h} /$ day in domestic including cattle rearing, agriculture and other activity. The village-wise variation in total time spent by the respondents was from $6.43 \mathrm{~h}$ to $10.49 \mathrm{~h}$ (minimum in Sikosa village and maximum in Latabod village). During peak seasons, the time spent by the respondents in agriculture varied from $6.5 \mathrm{~h} /$ day to $8.5 \mathrm{~h}$ /day in different blocks of the district of Durg Balod. the involvement of respondent were $42.83 \%$ in FYM application, $33.73 \%$ in preparatory work for seed-bed preparation, $53.53 \%$ in nursery preparation, $66.38 \%$ in sowing, $66.92 \%$ in intercultural operations, $46.84 \%$ in fertilizer application, $68.26 \%$ in harvesting, $51.79 \%$ in threshing, $52.20 \%$ in winnowing and $54.87 \%$ in post harvest operation. Out of this study it can be said that for appropriate mechanization different manual, animal, tractor and self propelled equipments/machines need to be introduced in the area either on custom hire basis or own basis along with facilities of minor repairing, which will enable the farmers for selective mechanization in reference to particular cropping system. 


\section{Introduction}

Farm mechanization means the introduction and use of non-biological power in carrying out various operations. The mechanization in the farm sector has to take several factors into considerations; it facilitates the speedy completion of farm operations with much ease. Farm mechanization is a different area of high-tech agriculture, in which modern machine are being put to use for land preparation, land development, inter culture operations, sowing transplanting harvesting threshing etc. Simply, it means the use of machinery for farm operations in the place of human and cattle. Farm mechanization has been helpful to bring about a significant improvement in agricultural productivity. Thus, there is strong need for mechanization of agricultural operations. The factors that justify the strengthening of farm mechanization in the country can be numerous. The timeliness of operations has assumed greater significant in obtaining optimal yields from different crops, which has been possible by way of mechanization (Singh, 2011).

The contribution of draught animal power in India has witnessed the most prominent change through decrease from $45.3 \%$ in 1971 to $8.02 \%$ in 2012 . The increase in power has been mainly through introduction of tractors, whose contribution has increased from $7.5 \%$ in 1971 to $46.7 \%$ in 2012. However draft animals, particularly bullocks/he buffaloes/camel; still continue to be a predominant source of energy for traction and rural transport in different parts of India. Today draft cattle provide about 50 million hp or about 35 million $\mathrm{kW}$ of energy in a year. More than 65 per cent of this energy is used for agriculture and the rest for transport. Over 150 Mha of land, farming about 65 per cent of the area sown, is cultivated through the use of draft animals every year. The average operational land holding in India has declined from 2-7 ha in 1960-61 to just half today. Most of farmers have small holdings and can hardly opt for complete mechanization. Therefore the use of draft animal power is going to be continued in India for many more years, especially in a state like Chhattisgarh (Anon., 1995).

\section{Power availability}

Indian farms had only $0.295 \mathrm{~kW} /$ ha in 1971 , dominated power (45.26\%). The power availability, however, increased over year at growth rates to $4.79,4.89 \%$ in each ten year till 1991. The contribution of draught animal power has witnessed the most prominent change through decrease from $45.3 \%$ in 1971 to $8.02 \%$ in 2012 . The increase in power has been mainly through introduction of tractors, whose contribution has increased from $7.5 \%$ in 1971 to $46.7 \%$ in 2012. Presently total power availability in Chhattisgarh is 1.09 $\mathrm{kW} / \mathrm{ha}$. and contribution of animal and human power is $27.4 \%$ and $48.39 \%$ respectively however animal farming cover about $40 \%$ of cultivated area (Mishra and Tripathi, 2006).

On an average $80 \%$ farmers have land holding less than 2 hectare. The small and marginal farmers do not have the capacity to purchase improved costly machinery or tractor. So they are dependent on the animals only. Chhattisgarh agriculture continues to be dependent upon human and bovine population. Tractor, power tiller, diesel engine and electric motor have supplemented the animate power. Among draft animals, bullock and He-buffaloes are used for farming operations in Chhattisgarh.

\section{High-tech agriculture}

High-tech agriculture tools raise the productivity of agriculture from 5 to $30 \%$. Seed-cum-fertilizer drill increase the 
production of land by 10 to $15 \%$ and plant protection equipment enhanced the production by 10 to $20 \%$. Similarly the harvesting equipment and irrigation pumps raised the productivity of land by 5 to $10 \%$ and 10 to $30 \%$ respectively thus Advantages of farm mechanization is bringing down the labour costs per unit of operation and saving time. Mechanization, therefore, increase the productivity of labor. For example a pair of bullock can plough the land in ten days but the tractor can plough the same piece of land efficiently within a day. Heavy jobs like digging, bunding, land development, land leveling etc., are easily done with the help of machinery.

\section{Farm mechanization}

Farm mechanization is the promotion and use of appropriate quality farm machinery to facilitate crop establishment, introduction of modern farm machinery on individual ownership basis or custom hire services, to ensure timeliness in farm operations and to increase the productivity of land and labour and to reduce drudgery of farmer. Mechanization helps in increasing economic return to the farmers by reducing the cost of cultivation, minimization of post harvest losses, to change the character of farm work, making it less arduous and more attractive, to improve the quality of field operation and providing better soil environment for seed germination and plant growth.

\section{Women in agriculture}

Women in rural India are extensively involved in the agricultural activities. However the nature and extent of their involvement varies from state to state and region to region. In most of the cases, they are involved in jobs that are more time consuming, require more patience and require less muscle power. They have low access to land and institutional credit. As per the Census 2001, total work force in India is 400 million of which $68.37 \%$ are male workers and $31.63 \%$ are female workers. Distribution of total workers by industrial category shows that agriculture sector still employs largest share of the workforce i.e., 58.24\% of the total workforce (inclusive of the cultivators and agriculture laborers). The total agriculture workforce in India is 234,270,000 as per 2001 census, of which $38.99 \%$ is contributed by female workforce and $60.93 \%$ is male workforce. In agriculture sector, out of the total women engaged, more women are employed as agriculture laborers rather than as cultivators both in absolute terms and as proportionately.

Chhattisgarh State is known as a rice bowl where rice culture is predominantly rain fed and approximately $85 \%$ of the rice crop in this region is direct-seeded. Most of the area is under a single cropping system. Rural women contribute much of the labor for rice production and other agricultural activities. More than $50 \%$ of the farm work is done by women in India (Chandurkar, 2001). Contributions of farm women in agriculture cannot be ignored.

Chaudhary and Singh (2003) support the above statement. They reported that women played considerable role in various agricultural activities such as pre-sowing, sowing and transplanting operations. Women's role was also reported in the preparation of compost and nursery preparation for vegetables. Women's role was found to be maximum in hoeing and weeding practices as intercultural operations. Harvesting and post harvesting operations were reportedly more suited to the physical condition of women. Reaping of crops, storage of food grains, storage of seed and processing of grains were reported to be mostly done by women. 
Therefore it can be said that the farm mechanization is a key factor for Agril. activity and role of women is also important for agriculture and allied activities. This case study has been planned for Durg Balod district to know the status of animal power utilization and involvement of farm women for agriculture and allied work.

\section{The specific objectives of this study were-}

To survey the present status of animal power utilization and the implements available with the farmers for recording of design and dimensions in selected village under prevailing cropping system.

1. To record the utilization of tractor and animal power utilization for agricultural operations.

2. To quantify farmwomen involvement in agriculture and allied activities under prevailing cropping system and practices.

3. To identify the operations/ equipments needing improvement and suggest strategy for appropriate mechanization in Durg Balod district.

\section{Materials and Methods}

Chhattisgarh state has been divided into three Agro-climatic zone viz. Chhattisgarh plains, Bastar Plateau and Northern Hill zone, covering $51.0 \%, 28.0 \%$ and $21.0 \%$ of the geographical area, respectively. The district from the Chhattisgarh plains was selected. Out of which two blocks namely Gunderdehi and Gurur block has been identified for the purpose of study. Two villages from each block were selected for conduction of data collection work. In this study 30 farmers including women from each of the village (total four) were interviewed personally for recording all necessary observation as per proforma developed.

\section{Location of the study area}

The District Head Quarter of Durg Balod is in Durg, which is situated on National Highway 200. Janjgir is $45 \mathrm{~km}$ from State capital Raipur through road route. District head quarter Durg is also connected with Rail Line of South-Eastern-Central Railway. It is situated on Howrah-Mumbai main line. State capital Raipur is $40 \mathrm{~km}$ from Durg through Rail route. The railway station of district Durg and Bhilai Nager.

On the basis of area Durg Balod district is the third smallest district of Chhattisgarh State having an area of $4015 \mathrm{~km}^{2}$. It is situated north of Mahanadi and is surrounded by Raipur, Rajnandgaon, Kanker \& Dhamtari districts. The total population of the district as per census 2011 is 1316140, having the highest population density of 342 within the State. The district is administratively divided into 8 development Blocks and having total 913 villages and 6 Townships.

The Gangrel project has been considered as life supporting canal for the district Durg Balod. The Normal rainfall is $1478 \mathrm{~mm}$ in the district. Total $889 \mathrm{~km}^{2}$ area of the district is covered by forest. Agriculture is the main occupation of the district. Net sown area is $2645.59 \mathrm{~km}^{2}$ (on 2000 data) with only 672.02 $\mathrm{km}^{2}$ is double cropped area. Principal crop is rice sown in $2605.62 \mathrm{~km}^{2}$ areas i.e. $98.34 \%$ of total sown area. $99.66 \%$ villages where provided with drinking water source. Almost $90 \%$ of drinking water supply is from Ground Water in the district. Total hand pumps are 5776 whereas power pumps are 3153 tapping ground water in the district. 84 water supply schemes are running tapping ground water in the district.

\section{Developing the interview schedule}

To collect information leading to fulfill the objectives of this study each farmer was 
interviewed separately. In order to obtain the complete information on each operation/ activity a detailed schedule (proforma) was developed by incorporating the suggestions given by AICRP on UAE and NRCWA, Bhopal. Prior to data collection. Questions pertaining to farmers detail, agril. operations, implements being used by farmers and their details, implements/power source available, animal power utilization, women contributions and specification of implements were asked and recorded.

\section{Method of data collection}

The data were collected through personal interview of the farmers and farmwomen on the pre - tested proforma by using recall method for all the selected farmers falling in different categories. The information about household activities was collected through interview of the counterparts of the farmers. Actual observations of some activities were also recorded during the field operations in a few villages.

The time and labour required for various farm operations mainly field preparation, sowing, transplanting, irrigation, manuring, fertilizer application, weeding, plant protection, harvesting, threshing, drying and transportation were recorded for each crop under study on the basis of the verbal interview of the farmers. Thus the data in terms of time and labour required to accomplish different field operations and household activities along with other basic information were collected individually from all the selected farmers.

\section{Data processing}

Adopting standard techniques suggested by the research workers the data thus collected was processed. First of all the data for animal power utilization was arranged separately for different categories of respondents for each village. The values thus found were arranged in tabular form separately for each category of farmers.

\section{Terminology used}

\section{Respondents}

The surveyed farm women from/of selected households under various categories are termed as respondents.

\section{Involvement of farm women in an operation}

It indicates the per cent of the respondent's involvements in the particular operation. If the involvement of farm women in intercultural operation was $89.96 \%$ means out of 100 respondents 89 respondent were involved in this operation.

\section{Mean involvement of farm women}

It is the average of ten farm operations. Based on respondents involvement in ten operations, their mean involvement was calculated to show their overall involvement in agriculture.

\section{Sampling procedure}

The main focus of study was on the animal power utilization, tractor power utilization and farm women and their involvement in agriculture and allied activities in the state. Therefore, only the draught animal, farm women and male farmers were considered separately for the study. To identify the location of survey sites in the selected district of the zone villages were grouped block wise. The farmers were selected randomly. After that population of the farmers were grouped under different categories for all the four villages. The categories viz. marginal (<1ha), small (1-2ha), semi-medium (2-4ha), medium (4-6ha) and large (>6ha) of farmers, selected in each of the village. 


\section{Selection and measurement of variables}

The main focus in this study was on assessing the farm women's involvement in agriculture and allied activities. However some social factors were also included with the assumption that they are important. Information on respondents knowledge, education, occupation, landholding status, availability of milch cattle and bullocks, method of grain storage, cropping pattern, time spent by respondents in domestic, cattle rearing, agriculture and other related activities from crop production to post harvest operations, drudgery level in carrying out these operations, possession, awareness and operation of improved farm tools and equipment, food items prepared at home own consumption, physical discomfort faced by the respondents during agricultural works, training needs, awareness about extension officials and decision making pattern in family.

\section{Statistical tools used for the analysis of data}

The frequency, percentage, mean and standard deviation were calculated for precise and meaning analysis and interpreting the data collected. Data were analyzed for the most part by using tabular form as for its inherent quality in portraying the true picture of farm women involvement in agriculture and allied activities in the state of Chhattisgarh. Farm women involvement was assessed as low level ( $<$ mean - SD), moderated level mean and high level (> mean $+\mathrm{SD})$ as suggested by Roy and Pathak (2000).

\section{Results and Discussion}

This chapter briefly presents the findings of the survey conducted in Durg-Balod district of Chhattisgarh Plains region. To find out the animal power utilization and women's power contribution in agriculture and allied activity under existing farm practices, a detailed survey of farm families comprising of different land holding sizes was conducted. Survey revealed that the respondents belong to different castes, and have education level from illiterate to college level. Many farmers, especially those who have their own irrigation sources, take summer paddy also.

\section{Villages under study and infrastructure facility}

The summary of information collected about the sample Blocks and villages are presented in Table.1 and 2. Two villages from each block were selected for survey work. It is observed that all the four villages are more or less of the same category on the basis of no. of farm families. All the villages were 15 to $17 \mathrm{~km}$ away to each other and these villages are connected by concrete muroom roads. In all the villages He-buffaloes is popular as a source of draught power. Total 30 respondents from each of the village were selected for personal interview to record the observations. The distribution of land holdings pattern in the study village were presented.

\section{General and social attributes}

The population density of Chhattisgarh state is 154 and in the district it is 342 persons per $\mathrm{km}^{2}$. The sex ratio of state and district is very similar to each other ranges between 989 and 999 female per thousand males. The main dialect of the district is chhattisgari. District has mainly backward class population and tribes like Satnami, Gond, Kanwar etc, are found in the district. District is well connected with the rest of the state through road and the two tehsils namely, Gunderdehi and Dondi are connected with railways. $98.15 \%$ villages of the district are electrified. There are eight blocks in the district (Dondi, gunderdehi, Gurur, Nawagarh, Bemetara, Patan, Saja and 
Dondi Lohara) out of them two blocks (Nawagarh, gurur and Gunderdehi) have only rural population and also urban both. In four blocks (Dhamdha, Bemetara, Nawagarh and gunderdehi) female population is more than males. About $22 \%$ and $13 \%$ population of the district are Schedule Caste (SC) and Schedule Tribes (ST), respectively. The percentage of ST population is highest $(27.14 \%)$ in Dondi, Gurur and Bemetara Block and lowest $(6.23 \%)$ in Patan, Saja and Nawagarh Block (Table - 1). There are six Block Resource Centers (BRCs), one each in all the blocks. As per 2011 census the male, female and total literacy is $82.21 \%, 50.41 \%$ and $66.26 \%$, respectively. Details of general information of the district and surveyed villages are summarized and shown in Fig.1.

\section{Draught animal power utilization}

Draught animal used in this region are small sized. The weight of a pair of He- buffaloes ranges between 550 to $900 \mathrm{~kg}$. The draught animals are primarily used for field preparation, biasi operation, threshing and transportation (Jogdand et al., 2011).

\section{Population of draught animal power and use of implements}

The summary of information collected about the sample villages viz. Arjunda, Sikosa, Latabod and Lohara are given in Table.2. One hundred twenty farmers were randomly selected out of four villages. Distribution in four villages were uniform i.e. 30 farmers in each village having He-buffaloes as a source of farm power.

It is observed that the entire four villagers are more or less of the same category on the basis of number of farm families. In all the four villages He-buffaloes and tractor is available as source of farm power. The higher population of He-buffaloes compared to bullocks showed the popularity of $\mathrm{He}$ buffaloes as a source of draught animal power. Few farmers have installed diesel engine and electric motor for lifting water. Highest number of diesel engine and electric pump has been recorded in village Latabod. The overall population of different animal drawn implement has also been recorded. Under animal drawn category, all are of traditional type except few farmer who have improved plough i.e. tendua plough.

\section{Month wise utilization of He-buffaloes power}

The month wise He-buffaloes power utilization for four villages from May 2011 to April 2012 is given. It was observed that the May, June, July and August months shows a rise in draught power utilization due to time of tillage and intercultural operation for paddy crop, He-buffaloes power utilization was confined for transportation in October and November. The utilization in the month of December and January is mainly for threshing operation just after the harvest of paddy. The he-buffalos are mostly unutilized in the month of February March and April due to monocarp nature of the area.

\section{Implement wise utilization of He-buffaloes power}

The annual utilization of different implements/operations were also recorded and it was found that in all the four villages the maximum utilization was noted for plough (Arjunda 3893h, Sikosa 3505h, Latabod $5187 \mathrm{~h}$, Lohara 5685h) followed by carting (Arjunda 1506h, Sikosa 2294h, Latabod 2442h, Lohara 3019h), leveling by wooden plank (Arjunda 918, Sikosa 790h, Latabod 1234h, Lohara 1009h) and animal treading (Arjunda 422h, Sikosa 390h, Latabod787h, Lohara 563h). 
The average implement wise utilization for different villages is given in Fig.2. The utilization of implements viz. Plough was maximum in village Latabod $57.77 \%$ followed by $55.33 \%, 53.75 \%$ and $50.22 \%$ in villages Sikosa, Arjunda, and Lohara respectively. Wooden plank was also utilized maximum in village Latabod $13.62 \%$ followed by $12.79 \%, 11.32 \%$ and $09.82 \%$ in villages Arjunda, Lohara and Sikosa respectively. The similar trend was observed in treading operation. However the values were on lower side and those were 08.16 in Arjunda followed by $06.26 \%, 05.59 \%$ and $05.48 \%$ in villages Latabod, Lohara and Sikosa village respectively. Under carting operation the utilization was next to ploughing operation which clearly indicated that carting system is popular amongst the farmers of the region. In Lohara village it was $32.87 \%$ followed by $29.38 \%, 25.30 \%$ and $22.34 \%$ in villages Sikosa, Arjunda and Latabod village respectively, as depicted in Table.3.

The highest utilization of He-buffaloes power per pair was noted in village Lohara and it was $342.5 \mathrm{~h}$ and lowest was $211.5 \mathrm{~h}$ in village Sikosa. The other villages observed the value of $301.6 \mathrm{~h}$ and $224.6 \mathrm{~h}$ for Latabod and Arjunda respectively. The implements being used by farmers for ploughing, biasi, leveling and yoke are presented.

The highest total annual utilization of Hebuffaloes power was noted in village Lohara and it was $10276 \mathrm{~h}$ and lowest was $6739 \mathrm{~h}$ in village Arjunda. The other villages observed the value of $9650 \mathrm{~h}$ and $6979 \mathrm{~h}$ for Latabod and Sikosa respectively.

The highest utilization of He-buffaloes power use/ha was noted in village Lohara and it was $118.556 \mathrm{~h} / \mathrm{ha}$ and lowest was $50.26 \mathrm{~h} / \mathrm{ha}$ in village Sikosa. The other villages observed the value of $111.68 \mathrm{~h} / \mathrm{ha}$ and $106.36 \mathrm{~h} / \mathrm{ha}$ for Arjunda and Latabod respectively (Table.3).

\section{Utilization pattern of farm tractors}

Utilization pattern of farm tractors in different agricultural operations for own land and for custom service in rabi and Kharif season is given in (Table.4), which revealed that the average annual use of the tractors was $382 \mathrm{~h}$ only in the district out of which for $59.16 \%$ of the time, the tractors were used for custom work and that of $40.85 \%$ of the time, for own work.

Maximum use of the tractor for $98 \mathrm{~h}(25.65 \%)$ was recorded in tillage operation, followed by threshing operation $57 \mathrm{~h}(14.92 \%)$ and sowing operation $67 \mathrm{~h}(17.53 \%)$. In the custom work, the maximum use of the tractors was found in tillage and transportation operations $42 \mathrm{~h}$ $(10.99 \%)$ and $39 \mathrm{~h}(10.21 \%)$, where as for own work, maximum use of the tractor was found was found in tillage operation $(14.66 \%)$.

Farm mechanization is a different area of high-tech agriculture, in which modern machine are being put to use for land preparation, land development, inter culture operations, sowing transplanting harvesting threshing etc. Simply, it means the use of machinery for farm operations in the place of human and cattle. Farm mechanization has been helpful to bring about a significant improvement in agricultural productivity. Thus, there is strong need for mechanization of agricultural operations. Women in rural India are extensively involved in the agricultural activities.

However the nature and extent of their involvement varies from state to state and region to region. In most of the cases, they are involved in jobs that are more time consuming, require more patience and require less muscle power.

Farm mechanization a key factor for agricultural activity and role of women is also important for agriculture and allied activities. 
This case study work has been completed and information on status of animal and tractor power utilization, farm women involvement in agriculture and allied activities and strategy for appropriate mechanization for DurgBalod district has been suggested.

Chhattisgarh state has been divided into three Agro-climatic zone wise

Chhattisgarh plains, Bastar Plateau and Northern Hill zone covering 51.0\%, 28.0\% and $21.0 \%$ of the geographical area, respectively. The district from the Chhattisgarh plains was selected, out of which two blocks namely Durg and Baloda block has been identified for the purpose of study.
Two villages from each block were selected for 65 conduction of survey work. In this study 30 farmers including women from each of the village (total four) were interviewed personally for recording all necessary observation as per proforma developed. To identify the location of survey sites in the selected district of the zone villages were grouped block -wise. The farmers were selected randomly. After that population of the farmers were grouped under different categories for all the four villages. The categories viz. marginal ( $<1 \mathrm{ha})$, small (12ha), semi-medium (2-4ha), medium (4-6ha) and large (>6ha) of farmers, selected in each of the village.

Table.1 Administrative Information

\begin{tabular}{|c|c|c|}
\hline Subdivisions & 5 & 04- (Balod, Durg, Bemetara, Nawagarh) \\
\hline Tahsils & & $\begin{array}{l}\text { 08-( Balod, Gurur, Dondi, Gunderdehi, Patan, Saja, } \\
\text { Bemetara, Nawagarh) }\end{array}$ \\
\hline R.I. Mandal & & $\begin{array}{l}\text { 12- (Balod, Gunderdehi, Gurur, Dondi, Dondi Lohara, } \\
\text { Arjunda, Saja, Patan, Nawagarh, Bemetara, Dhamdha, } \\
\text { Bhilai) }\end{array}$ \\
\hline Patwari Halka & \multicolumn{2}{|c|}{ Total- 232} \\
\hline Blocks/Janpad & \multicolumn{2}{|r|}{06 - (Gunderdehi, Gurur, Dondi, Dondi Lohara, Saja, Patan) } \\
\hline \multicolumn{3}{|l|}{ Panchayat } \\
\hline Panchayats & \multicolumn{2}{|c|}{ Total -522} \\
\hline \multirow[t]{2}{*}{ Villages } & \multicolumn{2}{|r|}{ (a) Revenue Villages- 913, (b) Forest Villages- 2, } \\
\hline & \multicolumn{2}{|c|}{ (c) Total Villages- 915} \\
\hline Municipality & & 04 - (Balod, Durg) \\
\hline $\begin{array}{c}\text { Nagar } \\
\text { Panchayat }\end{array}$ & \multicolumn{2}{|r|}{ 05- (Balod, Durg, Bemetara, Nawagarh, Dhamdha) } \\
\hline
\end{tabular}


Table.2

\begin{tabular}{|c|c|c|c|c|}
\hline S.No. & $\begin{array}{l}\text { Tractor used in } \\
\text { different agrl. } \\
\text { operation }\end{array}$ & $\begin{array}{c}\text { Average Annual } \\
\text { agril. Use of tractor } \\
\text { for personal land } \\
\text { h (\%) }\end{array}$ & $\begin{array}{l}\text { Average Annual } \\
\text { agril. Use of } \\
\text { tractor for custom } \\
\text { service land }(\%)\end{array}$ & $\begin{array}{c}\text { Average annual } \\
\text { other use of tractor } \\
\text { for custom service } \\
(\%)\end{array}$ \\
\hline 1. & Tillage & $\begin{array}{c}56 \\
10.66\end{array}$ & $\begin{array}{c}42 \\
10.99\end{array}$ & ---- \\
\hline 2. & Sowing & $\begin{array}{c}30 \\
(7.85 \%)\end{array}$ & 37 & ----- \\
\hline 3. & Leveling & $\begin{array}{c}4 \\
1.05\end{array}$ & $\begin{array}{c}9 \\
2.36\end{array}$ & ---- \\
\hline 4. & Threshing & $\begin{array}{c}20 \\
5.24\end{array}$ & $\begin{array}{c}37 \\
9.69\end{array}$ & ---- \\
\hline 5. & Transportation & $\begin{array}{c}32 \\
8.38\end{array}$ & $\begin{array}{c}39 \\
10.21\end{array}$ & ---- \\
\hline 6. & Irrigation & ---- & $\begin{array}{c}3 \\
0.79\end{array}$ & ---- \\
\hline 7. & Miscellaneous use & $\begin{array}{c}14 \\
3.66\end{array}$ & ------ & $\begin{array}{c}59 \\
15.45\end{array}$ \\
\hline & Total & $\begin{array}{c}156 \\
40.85\end{array}$ & $\begin{array}{c}167 \\
43.72\end{array}$ & $\begin{array}{c}59 \\
15.45\end{array}$ \\
\hline
\end{tabular}

Table.3 Population of power source in selected village

\begin{tabular}{|c|c|c|c|c|c|}
\hline \multirow[t]{2}{*}{ S.no. } & \multirow[t]{2}{*}{ Particulars } & \multicolumn{2}{|c|}{ Gunderdehi Block } & \multicolumn{2}{|c|}{ Gurur Block } \\
\hline & & Arjunda & Lohara & Sikosa & Latabod \\
\hline 1 & Total Area (ha) & 537.452 & 569.398 & 586.621 & 687.907 \\
\hline 2 & Cultivable Area (ha) & 409.314 & 422.153 & 439.900 & 542.923 \\
\hline 3 & Irrigated Area (ha) & 409.314 & 422.000 & 427.000 & 405.000 \\
\hline \multirow[t]{3}{*}{4} & Major Crop Grown & & & & \\
\hline & (a) Kharif & \multicolumn{2}{|c|}{ Paddy, Arhar } & & \\
\hline & (b) Rabi & \multicolumn{4}{|c|}{ Wheat, Bengal Gram, Sarso, Tiwra, Alsi } \\
\hline 5 & Major Crop Rotation & \multicolumn{2}{|c|}{ Paddy, Wheat, Moong } & & \\
\hline 6 & No. of Farm families & 342 & 408 & 482 & 805 \\
\hline 7 & Bullocks (Nos.) & 10 & 16 & 138 & 193 \\
\hline 8 & He-buffaloes (Nos.) & 200 & 250 & 240 & 316 \\
\hline 9 & Tractors (Nos.) & 9 & 14 & 22 & 9 \\
\hline 10 & Power Tiller Reaper (Nos.) & 2 & 3 & 3 & 0 \\
\hline 11 & Country Plough (Nos.) & 105 & 256 & 327 & 342 \\
\hline 12 & Bollock Cart (Nos.) & 104 & 254 & 322 & 340 \\
\hline 13 & Gobar Gas Plant (Nos.) & 8 & 0 & 7 & 36 \\
\hline 14 & Vermi Compost (Nos.) & 10 & 0 & 0 & 0 \\
\hline 15 & Tube Well (Nos.) & 7 & 2 & 6 & 4 \\
\hline 16 & Electric Motor (Nos.) & 20 & 30 & 11 & 5 \\
\hline 17 & Diesel Engines (Nos.) & 30 & 70 & 9 & 16 \\
\hline
\end{tabular}


Plate.1 Map of Durg Balod district

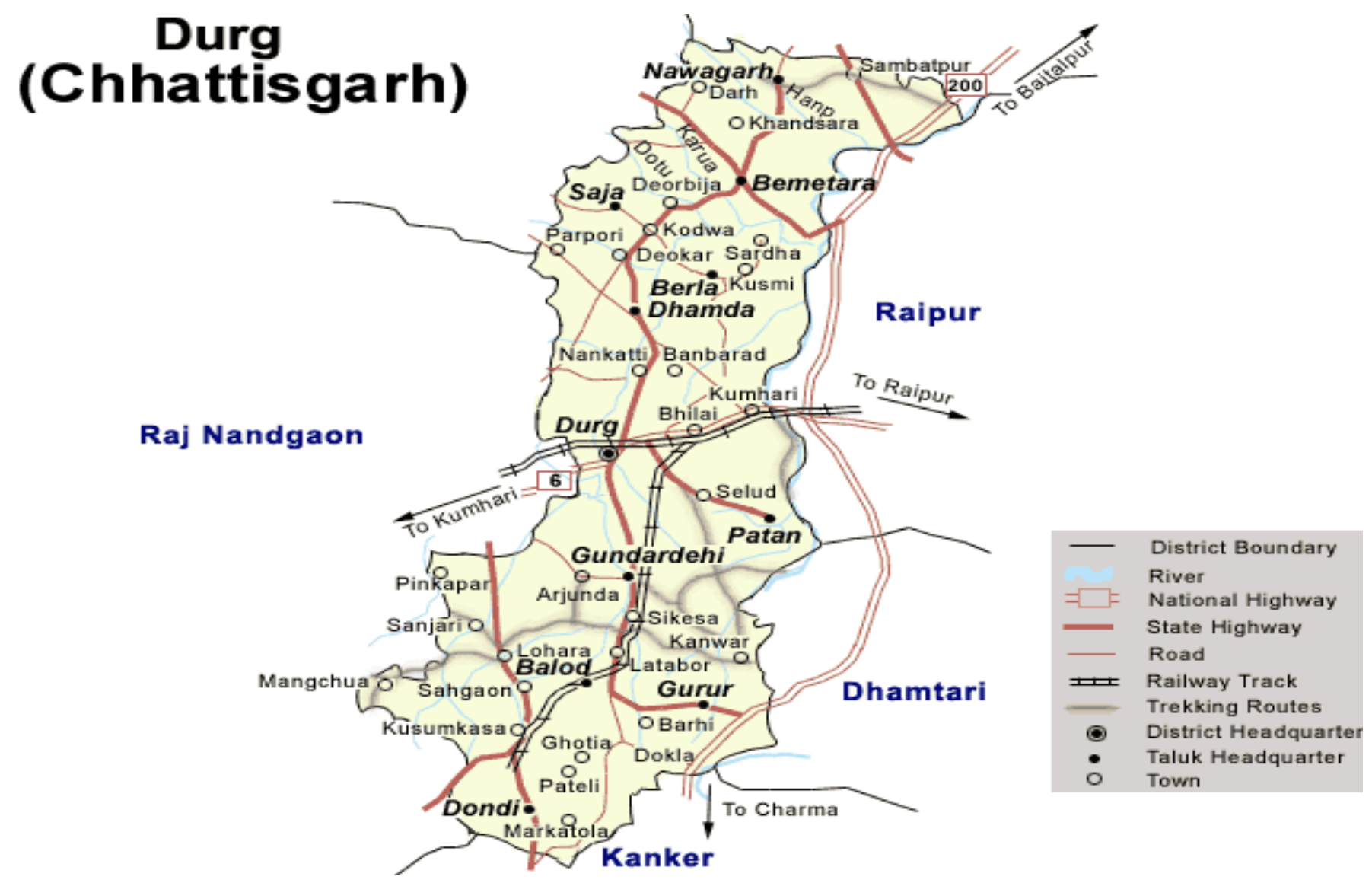


Table.4 Average utilization of He-buffaloes power (h)

\begin{tabular}{|c|c|c|c|c|c|c|c|c|c|c|}
\hline \multirow{2}{*}{$\begin{array}{l}\text { S. } \\
\text { No. }\end{array}$} & \multirow{2}{*}{$\begin{array}{l}\text { Name of } \\
\text { Village }\end{array}$} & \multirow{2}{*}{$\begin{array}{c}\text { Area } \\
\text { (ha) }\end{array}$} & \multirow{2}{*}{$\begin{array}{l}\text { No. } \\
\text { of } \\
\text { Draft } \\
\text { Pair }\end{array}$} & \multicolumn{4}{|c|}{ Implementwise Utilization } & \multirow{2}{*}{$\begin{array}{c}\text { Total } \\
\text { Utilization } \\
\text { (h) }\end{array}$} & \multirow{2}{*}{$\begin{array}{c}\text { Utiliz } \\
\text { ation } \\
\text { /Pair } \\
\text { (h) }\end{array}$} & \multirow[t]{2}{*}{ Use/ha } \\
\hline & & & & $\begin{array}{c}\text { Plough } \\
(\%)\end{array}$ & $\begin{array}{c}\text { Woonn } \\
\text { Plank } \\
(\%)\end{array}$ & $\begin{array}{c}\text { Threshing } \\
(\%)\end{array}$ & $\begin{array}{c}\text { Carting } \\
(\%)\end{array}$ & & & \\
\hline \multirow[t]{2}{*}{1} & Arjunda & 46.86 & 30 & 3893 & 918 & 422 & 1506 & 6739 & 224.6 & 111.68 \\
\hline & & & & 57.77 & 13.62 & 6.26 & 22.34 & & & \\
\hline \multirow[t]{2}{*}{2} & Sikosa & 93.23 & 33 & 3505 & 790 & 390 & 2294 & 6979 & 211.5 & 50.26 \\
\hline & & & & 50.22 & 11.32 & 5.59 & 32.87 & & & \\
\hline \multirow[t]{2}{*}{3} & Latabod & 67.77 & 32 & 5187 & 1234 & 787 & 2442 & 9650 & 301.6 & 106.36 \\
\hline & & & & 53.75 & 12.79 & 8.16 & 25.30 & & & \\
\hline \multirow[t]{2}{*}{4} & Lohara & 61.21 & 30 & 5685 & 1009 & 563 & 3019 & 10276 & 342.5 & 118.56 \\
\hline & & & & 55.33 & 9.82 & 5.48 & 29.38 & & & \\
\hline
\end{tabular}

\begin{tabular}{|c|c|c|c|c|}
\hline S.No. & $\begin{array}{l}\text { Tractor use in } \\
\text { different } \\
\text { agricultural } \\
\text { operation }\end{array}$ & $\begin{array}{l}\text { Average annual } \\
\text { agril. use of } \\
\text { tractor for } \\
\text { personal land } \\
\text { (h) }(\%)\end{array}$ & $\begin{array}{l}\text { Average annual } \\
\text { agril. use of } \\
\text { tractor for } \\
\text { custom } \\
\text { service land } \\
\text { (h) }(\%)\end{array}$ & $\begin{array}{l}\text { Average annual } \\
\text { other use of } \\
\text { tractor for } \\
\text { custom } \\
\text { service } \\
\text { (h) }(\%)\end{array}$ \\
\hline \multirow[t]{2}{*}{1.} & Tillage & 56 & 42 & ----- \\
\hline & & $(14.66 \%)$ & $(10.99 \%)$ & \\
\hline \multirow[t]{2}{*}{2.} & Sowing & 30 & 37 & ----- \\
\hline & & $(7.85 \%)$ & $(9.69 \%)$ & \\
\hline \multirow[t]{2}{*}{3.} & Leveling & 4 & 9 & ----- \\
\hline & & $(1.05 \%)$ & $(2.36 \%)$ & \\
\hline \multirow[t]{2}{*}{4.} & Threshing & 20 & 37 & ----- \\
\hline & & $(5.24 \%)$ & $(9.69 \%)$ & \\
\hline \multirow[t]{2}{*}{5.} & Transportation & 32 & 39 & ----- \\
\hline & & $(8.38 \%)$ & $(10.21 \%)$ & \\
\hline \multirow[t]{2}{*}{6.} & Irrigation & ----- & 3 & ----- \\
\hline & & & $(0.79 \%)$ & \\
\hline \multirow[t]{4}{*}{7.} & Annual & 14 & ----- & 59 \\
\hline & miscellaneous use & $(3.66 \%)$ & & $(15.45 \%)$ \\
\hline & Total & 156 & 167 & 59 \\
\hline & & $(40.85 \%)$ & $(43.72 \%)$ & $(15.45 \%)$ \\
\hline
\end{tabular}


Table.5 Women's friendly tools/implement

\begin{tabular}{|c|c|c|}
\hline S.No & Name of implement & Cost \\
\hline $\mathbf{1 .}$ & Hand wheel hoe & 920 \\
\hline $\mathbf{2 .}$ & Ambika paddy weeder & 740 \\
\hline $\mathbf{3 .}$ & Maize sheller & 50 \\
\hline $\mathbf{4 .}$ & Winnowing fan & 1750 \\
\hline $\mathbf{5 .}$ & Cono weeder & 1350 \\
\hline $\mathbf{6 .}$ & Soyabeen weeder & 570 \\
\hline $\mathbf{7 .}$ & Dev Agro serrated sickel & 50 \\
\hline
\end{tabular}

Table.6 Animal drawn implements:

\begin{tabular}{|c|c|c|}
\hline S.No & Name of implement & Cost \\
\hline $\mathbf{1 .}$ & Mould board plough & 1550 \\
\hline $\mathbf{2 .}$ & Tendua plough & 1680 \\
\hline $\mathbf{3 .}$ & Biasi plough & 1040 \\
\hline $\mathbf{4 .}$ & Indira seed drill & 5600 \\
\hline $\mathbf{5 .}$ & Paddy puddler & 4520 \\
\hline $\mathbf{6 .}$ & Harrow patela & 4000 \\
\hline
\end{tabular}

Table.7 Tractor drawn implements

\begin{tabular}{|c|c|c|}
\hline S.No. & Name of implement & Cost \\
\hline $\mathbf{1 .}$ & MB Plough & 26000 \\
\hline $\mathbf{2 .}$ & Harrow puddler & 28000 \\
\hline $\mathbf{3 .}$ & Cultivator & 27000 \\
\hline $\mathbf{4 .}$ & Rotavator & 27000 \\
\hline $\mathbf{5 .}$ & Disc harrow & 19500 \\
\hline $\mathbf{6 .}$ & Cultivator cum seed drill & 27000 \\
\hline $\mathbf{7 .}$ & Seed cum fertilizer drill & 31080 \\
\hline $\mathbf{8 .}$ & Zero till seed drill & 27000 \\
\hline $\mathbf{9 .}$ & Frount mounted reaper & 175000 \\
\hline $\mathbf{1 0 .}$ & Paddy thresher & 27000 \\
\hline
\end{tabular}


Fig. 1 Category wise population in different blocks

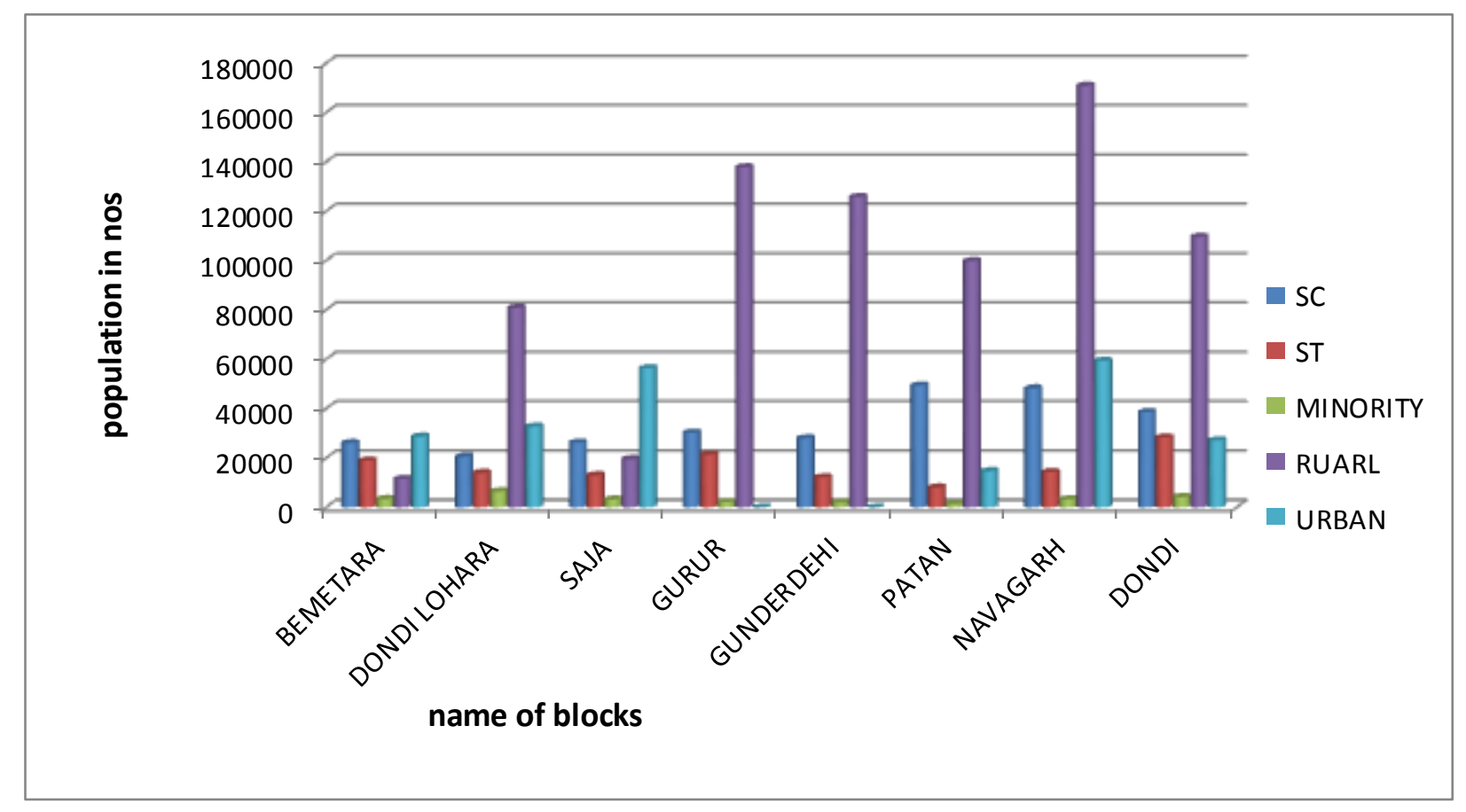

Fig.2 Sex wise population in different blocks

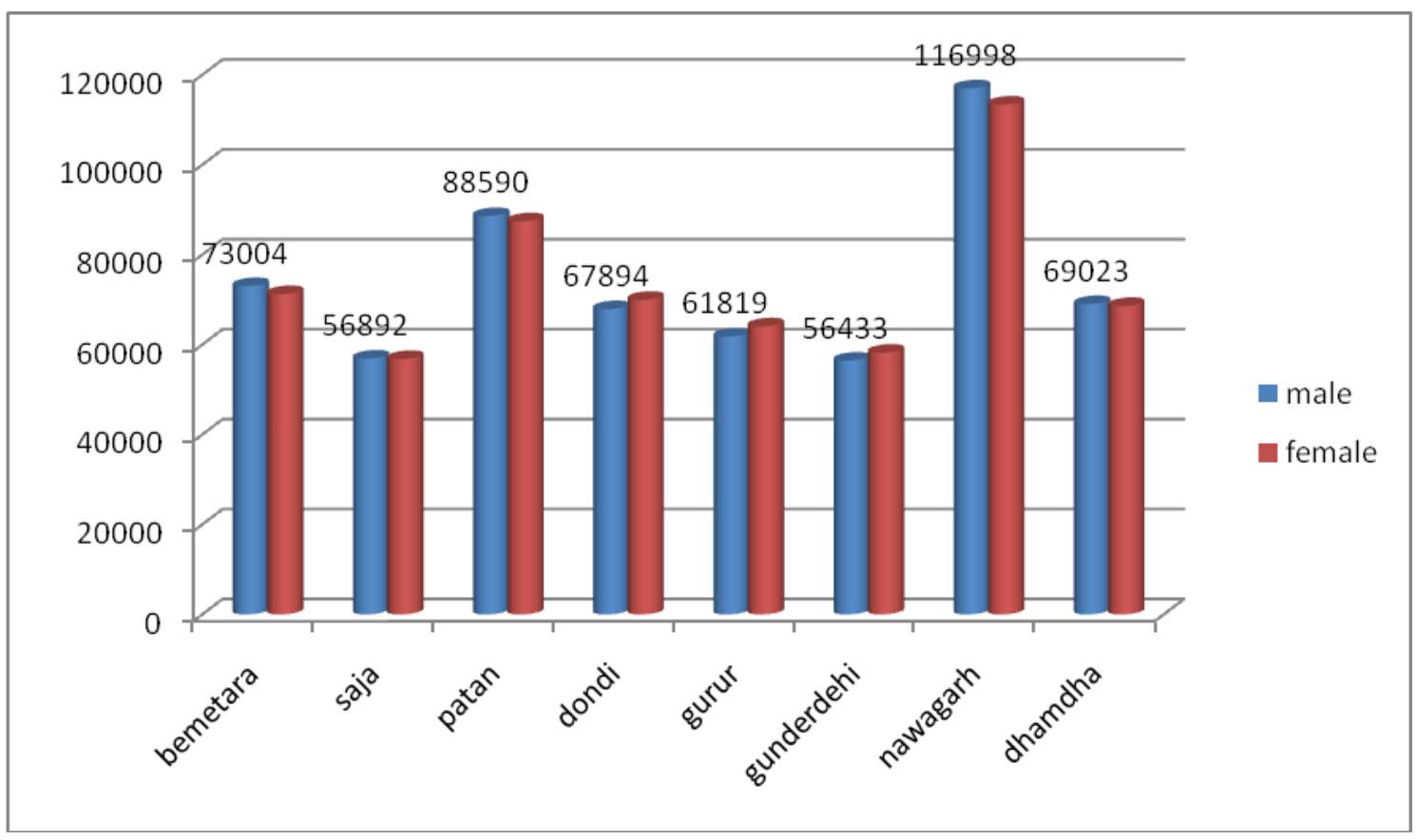




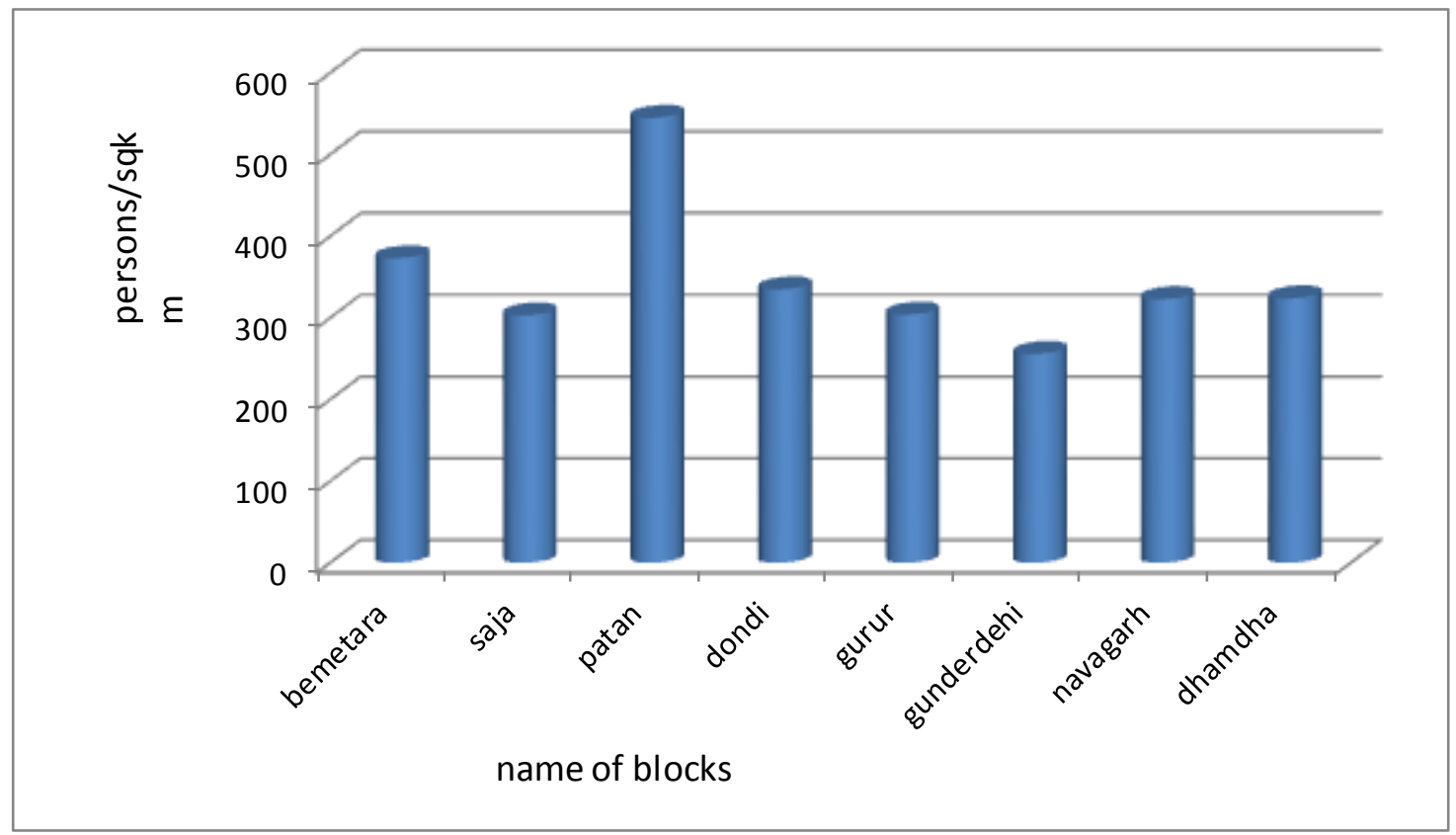

The frequency, percentage, mean and standard deviation were calculated for precise and meaning analysis and interpreting of the data collected. Data were analyzed for the most part by using tabular form as for its inherent quality in portraying the true picture of farm women involvement in agriculture and allied activities in the state of Chhattisgarh. SD farm women involvement was assessed as low level ( $<$ mean - SD), moderated level and high level $(>$ mean $+\mathrm{SD})$ as suggested by Roy and Pathak (2000).

The month wise He-buffaloes power utilization for four villages from May 2009 to April 2010, it was observed that May, June, July and August months shows a rise in draught power utilization due to time of tillage and intercultural operation for paddy crop, He-buffaloes power utilization was confined for transportation in October and November. The utilization in the month of December and January is mainly for threshing operation just after the harvest of paddy. The he-buffalos are mostly unutilized in the month of February March and April due to monocarp nature of the area.

\section{References}

Aggarwal, M. 2003. Economic Participation of Rural Women in Agriculture. Economic Empowerment of Rural Women in India, Edited by Gopal Singh 2003, RBSA Publications Jaipur, Rajasthan.

Anonymous. 1995. Utilization of animal energy through effective animal machine system in Baster region. Final report of ICAR ahhoc project. pp. 1-69. Anonymous. 2001. Empowerment of Women in Agriculture, Policy Paper11; National Academy of Agricultural Science, India, September 2001.

Anonymous. 2005. The Kamdhenu bullocks drawn tractor. Bhartiya Cattle Resource Development Foundation. Rajasthan. Website www.cowindia.org Bargali, S.S., Pandey, K., Singh, L. and Shrivastava, S.K. 2009. Participation of rural women in rice-based agroecosystems. IGKV, Raipur.

Chandurkar, P.S. 2001. Training and education on IPM. IPM Mitr. 11:91-97.

Chaudhary, H. and Singh, S., 2003. Farm Women in Agriculture Operations. 
Agricultural Extension Review. 15(1): 21-23.

Chaudhury, Sarmishtha. 2004. Invisible Activities of Rural Women. Kurukshetra, Vol. 52, No. 9, July 2004. system for rice cultivation under rainfed condition. Agricultural Mechanization in Asia, Africa and Latin America, 30(3): 28-30.

Dave, A.K. 1999. Animal drawn tillage

\section{How to cite this article:}

Dipti Sahu and Vinod Kumar Sahu. 2020. Status of Farm Mechanization in Durg, Balod District of Chhattisgarh Plains- A Case Study. Int.J.Curr.Microbiol.App.Sci. 9(05): 1433-1448. doi: https://doi.org/10.20546/ijcmas.2020.905.164 